Institute of $\mathbf{F}_{\text {ood and }} \mathbf{A}$ gricultural $\mathbf{S}_{\text {ciences }}$

\title{
Fertilizing and Liming Forage Crops ${ }^{1}$
}

\author{
C. G. Chambliss and G. Kidder ${ }^{2}$
}

The six soil-supplied nutrients required by plants in the largest quantities are nitrogen $(\mathrm{N})$, phosphorus $(\mathrm{P})$, potassium $(\mathrm{K})$, calcium $(\mathrm{Ca})$, magnesium $(\mathrm{Mg})$, and sulfur (S). Micronutrents (iron, copper, zinc, manganese, boron, molybdenum, and chlorine) are also essential but are used by the plant in very small amounts. The soil can supply the plant with most, if not all, of these nutrients, but often the supply of one or more of the nutrients is insufficient for optimum growth.

Nitrogen is the most important fertilizer nutrient used on grass pastures. It is the nutrient that is most likely to be deficient and therefore the one that most often results in increased forage production.

Phosphorus may be deficient in some areas, but some Florida soils are high in native P. Also, some grasses may extract sufficient $P$ from the subsoil, even when the P level in the surface soil is low. Potassium may need to be added to some pastures. The other nutrients are seldom a problem in pastures where considerable recycling of these nutrients occur. Under intensive hay or silage production, where nutrients are removed from the land, annual applications of $\mathrm{P}$ and $\mathrm{K}$ are needed. Potassium can very quickly become deficient. Calcium, magnesium, sulfur, and some micronutrients may also become deficient.

If the soil is at or above the target $\mathrm{pH}$, calcium in the soil should be sufficient for optimum plant growth. If the soil $\mathrm{pH}$ needs to be adjusted upward, the level of magnesium may be low in some soils and can be increased by liming with dolomitic limestone, or magnesium can be added to the fertilizer.

There is no soil test for sulfur, nor any specific recommendations for its use. It is suspected that some areas of Florida may be deficient in sulfur (in some years and on some crops). Sulfur deficiency may be seen under intensive hay or silage production. It is suggested that if a producer is concerned or suspects a sulfur deficiency, some sulfur be added by using ammonium sulfate as the nitrogen source in the first spring application.

Under most circumstances, micronutrients are not deficient and therefore should not be applied until a deficiency of a specific nutrient is confirmed. It is suggested that for new plantings of forages on virgin flatwood soils, $3 \mathrm{lb} / \mathrm{A}$ of copper should be applied with the initial fertilization. Also, see IFAS fact sheet SS-AGR-152 Fertilization of Agronomic Crops for a more extensive discussion of micronutrients.

\footnotetext{
1. This document is SS-AGR-176, one of a series of the Agronomy Department, Florida Cooperative Extension Service, Institute of Food and Agricultural Sciences, University of Florida. This publication is also part of the Florida Forage Handbook, an electronic publication of the Agronomy Department. For more information you may contact the editor of the Florida Forage Handbook, C. G. Chambliss (cgc@ mail.ifas.ufl.edu). Published March 2003. Please visit the Edis website at http://edis.ifas.ufl.edu.

2. C. G. Chambliss, associate professor, Agronomy Department; G. Kidder, professor, Soil and Water Science Department; Cooperative Extension Service, Institute of Food and Agricultural Sciences, University of Florida, Gainesville, 32611.
}

The Institute of Food and Agricultural Sciences is an equal opportunity/affirmative action employer authorized to provide research, educational information and other services only to individuals and institutions that function without regard to race, color, sex, age, handicap, or national origin. For information on obtaining other extension publications, contact your county Cooperative Extension Service office. Florida Cooperative Extension Service/Institute of Food and Agricultural Sciences/University of Florida/Christine Taylor Waddill, Dean. 
Only the nutrients that are needed by the crop should be included in the fertilizer. If a soil test indicates that phosphorous is high, then no phosphorous should be included in the fertilizer.

How does a manager decide if fertilizer or lime should be applied to a pasture or forage crop? Fertilizer and/or lime should be applied (1) if an increase in forage growth can be expected, (2) if the extra forage is needed, and (3) if a return on the investment can be expected. Experience of the forage manager, along with soil testing for $\mathrm{pH}, \mathrm{P}$, and $\mathrm{K}$, can be used in making a decision about liming and fertilizing with $\mathrm{P}$ and $\mathrm{K}$, especially for hay or silage production. There is no point in fertilizing if the extra forage produced is not used. To make a profit on the investment, the forage must be harvested, and the product (animal weight gain, milk, hay, or silage) must be marketed.

Fertilizer should usually be applied at the beginning of the growing season for the particular forage in question. Warm-season perennial grasses should be fertilized in the early spring (February to March) - this stimulates needed production at a critical time. Some pasture grasses may be given an additional application of nitrogen in June if extra forage is needed, but this is usually not the case for a beef cow/calf operation. Although bahiagrass gives little, if any, response to a late-summer/fall application, limpograss, rhodesgrass, and stargrass do. These grasses can be fertilized in the late summer or early fall to extend the grazing season or, in the case of limpograss, for stockpiling. Timely application of fertilizer can be used to increase forage yield and quality, improve stand persistence, and provide for better distribution of forage across the growing season. The producer should consider that the response obtained from an application of fertilizer is influenced by many other factors such as solar radiation, temperature, soil moisture, and grazing management. Overgrazing (excessive defoliation) limits the plants' ability to respond to the added nutrients and thereby reduces potential yield.

Some grasses, such as the stargrasses and some of the improved hybrid bermudagrasses, need to be fertilized annually or maintained in a high-fertility environment in order to maintain a good stand. On the other hand, some ranch managers with large, extensive operations may only fertilize their bahiagrass or limpograss once every three years. These grasses can persist under minimum fertility if they are not overgrazed.

\section{Fertilization Recommendations for Specific Forages}

The following comments are adapted from the publication SL 129, UF/IFAS Standardized Fertilization Recommendations for Agronomic Crops, G. Kidder, C. G. Chambliss and R. Mylavarapu.

\section{Fertilizing for Establishment of Perennial Grasses}

Applying nutrients on a clean-tilled seedbed before plant roots are present increases the risk of losing some or all of the nutrients by leaching. Heavy rainfall events on Florida's sandy soils can move nitrogen and potassium downward in the soil profile and out of reach of plant roots that will be developing later. Therefore, it is suggested that where possible, nutrients (fertilizer) not be applied until plant roots are present to take up the nutrients.

For establishment of new plantings, apply $30 \mathrm{lb}$ N/A, all of the soil-test-recommended $\mathrm{P}_{2} \mathrm{O}_{5}$, and 50\% of the $\mathrm{K}_{2} \mathrm{O}$ as soon as plants emerge. Apply the remaining $\mathrm{K}_{2} \mathrm{O}$ and 60 to $70 \mathrm{lb}$ N/A 30 to 50 days later.

When the new plants are small, only a limited amount of $\mathrm{N}$ and $\mathrm{K}_{2} \mathrm{O}$ are applied, with additional $\mathrm{N}$ and $\mathrm{K}_{2} \mathrm{O}$ being applied later to encourage the new plants to continue growing, spreading, and developing into a full and complete stand of grass.

\section{Fertilizing Bahiagrass}

\section{Grazed Bahiagrass - South and Central Florida}

In the region of the state located south of a line that runs east to west through Orlando, recent field research has shown no yield benefit for $\mathrm{P}$ and $\mathrm{K}$ fertilization of grazed bahiagrass pastures, even when soil tests indicate that these nutrients are low. Therefore, neither soil testing for $\mathrm{P}$ and $\mathrm{K}$ nor application of these nutrients to bahiagrass pastures 
on a routine basis in this region is recommended. It is recommended that 50 to 60 pounds of $\mathrm{N}$ be applied to these pastures in the spring. $\mathrm{P}$ and $\mathrm{K}$ may need to be added to these pastures at some future time if a pasture begins to perform poorly. If you plan to take a cutting of hay from a pasture, see the subsequent section on Bahiagrass Cut Sometimes for Hay.

\section{Grazed Bahiagrass - North Florida}

North of Orlando, three fertilization options are available. The producer should choose the option that most closely fits his or her fertilizer budget, management objectives, and land capability.

1) Low-nitrogen option (for grazed pastures only): Apply around $50 \mathrm{lb}$ N/A in the early spring. Do not apply $\mathrm{P}$ or $\mathrm{K}$, since at this low level of $\mathrm{N}$ application, $\mathrm{N}$ is still the nutrient limiting plant growth. Do not use this option if you cut hay, because nutrient removal by hay is much greater than by grazing animals.

2) Medium-nitrogen option: Apply around 100 $\mathrm{lb}$ N/A in the early spring to provide much needed forage. At this level of $\mathrm{N}$ fertilization, $\mathrm{P}$ and $\mathrm{K}$ may be limiting if your soil tests low in these nutrients. Apply $25 \mathrm{lb}_{2} \mathrm{O}_{5} / \mathrm{A}$ if your soil tested very low or low in $\mathrm{P}$ and none if it tested medium or high. Apply $50 \mathrm{lb} \mathrm{K}_{2} \mathrm{O} / \mathrm{A}$ if your soil tests very low or low in $\mathrm{K}$ and none if it tests medium or high. Retest your soil every third year to verify $\mathrm{P}$ and $\mathrm{K}$ levels. If you plan to make a late-season cutting of hay, apply $60 \mathrm{lb}$ N/A between August 1 and 15 (about 6 weeks before the growing season ends).

3) High Nitrogen Option: Apply $160 \mathrm{lb}$ N/A and the soil-test recommended rates of $\mathrm{P}_{2} \mathrm{O}_{5}$ and $\mathrm{K}_{2} \mathrm{O}$ for each of your pastures. Split the $\mathrm{N}$ into two applications of $80 \mathrm{lb}$ N/A each, applying in early spring and early summer. The fertilization rates suggested in this option are high enough to allow bahiagrass pasture to achieve well above average production. Management and environmental factors will determine how much of the potential production is achieved and how much of the forage is utilized. A single cutting of hay can be made without need for additional fertilization.

\section{Bahiagrass Cut Sometimes for Hay}

For a Single Cut Per Year from Pastures: If you used the low-N option of pasture fertilization, apply $80 \mathrm{lb} \mathrm{N} / \mathrm{A}$ and the soil-test recommended amount of $\mathrm{P}_{2} \mathrm{O}_{5}$ and $\mathrm{K}_{2} \mathrm{O}$ no later than six weeks before the growing season ends. If you used the Medium-N option of pasture fertilization, apply $80 \mathrm{lb} \mathrm{N}$ and $40 \mathrm{lb}$ $\mathrm{K}_{2} \mathrm{O} / \mathrm{A}$ no later than six weeks before the growing season ends. If you used the High-N option of pasture fertilization, you do not need any additional fertilization to make one cut of hay.

\section{Bahiagrass Grown Only for Hay}

For Multiple Cuts of Hay: Apply $80 \mathrm{lb}$ N/A and the soil-test recommended rates of $\mathrm{P}_{2} \mathrm{O}_{5}$ and $\mathrm{K}_{2} \mathrm{O}$ in early spring. Apply an additional $80 \mathrm{lb} \mathrm{N}$ and $40 \mathrm{lb}$ $\mathrm{K}_{2} \mathrm{O} / \mathrm{A}$ after each cutting, except the last in the fall. Include $20 \mathrm{lb}$ of $\mathrm{P}_{2} \mathrm{O}_{5} / \mathrm{A}$ in the supplemental fertilizer if the soil tested low or medium in $\mathrm{P}$.

\section{Bahiagrass for Seed Production}

Apply 60 to $80 \mathrm{lb}$ N/A and the soil-test recommended $\mathrm{P}$ and $\mathrm{K}$ in February or March. Graze until May, June or July, depending on variety. Remove cattle as soon as the first seed heads start to emerge and apply an additional 60 to $80 \mathrm{lb}$ N/A.

If the bahiagrass is not grazed, do not apply fertilizer in February or March since this may stimulate excessive top growth. Mowing from February to April may be needed to remove excessive top growth. Apply the soil test recommended $\mathrm{P}$ and $\mathrm{K}$ and 60 to $80 \mathrm{lb} \mathrm{N} / A$ before seed heads first appear. Fertilize Pensacola in March/April and Argentine and Paraguay in May/June.

\section{Fertilizing Established Pastures of Bermudagrass, Stargrass, Digitgrass, (Pangola), Rhodesgrass, and Suerte}

Pasture production: For grazed, established stands, apply $80 \mathrm{lb} \mathrm{N} / \mathrm{A}$, all of the soil-test-recommended $\mathrm{P}_{2} \mathrm{O}_{5}$, and $50 \%$ of the $\mathrm{K}_{2} \mathrm{O}$ in early spring. Apply an additional 60 to $80 \mathrm{lb}$ N/A and the remaining $\mathrm{K}_{2} \mathrm{O}$ at midseason. In central and south Florida, the midseason application can be delayed and applied in September to early October for fall production on stargrass, hybrid bermudagrasses, and 
rhodesgrass. Under intensive management in central and south Florida, up to $200 \mathrm{lb}$ N/A /year may be economically viable for stargrass and bermudagrass. In this situation, apply $80 \mathrm{lb} \mathrm{N} / \mathrm{A}$, all of the $\mathrm{P}_{2} \mathrm{O}_{5}$, and $50 \%$ of the $\mathrm{K}_{2} \mathrm{O}$ in early spring. Follow with $50 \mathrm{lb}$ N/A in midseason, and $70 \mathrm{lb}$ N/A and the other $50 \%$ of the $\mathrm{K}_{2} \mathrm{O}$ in mid-to-late September.

\section{Fertilizing Established Pastures of Limpograss}

For grazed established stands, apply $60 \mathrm{lb}$ N/A and all of the soil test recommended $\mathrm{P}_{2} \mathrm{O}_{5}$ and $\mathrm{K}_{2} \mathrm{O}$ in late winter or early spring. Apply an additional $60 \mathrm{lb}$ $\mathrm{N}$ in late summer or early fall. For a minimum fertilization alternative, ignore the $\mathrm{P}$ and $\mathrm{K}$ recommendation and apply only $60 \mathrm{lb} \mathrm{N}$ per year.

\section{Fertilizing for Hay or Silage Production from Perennial Grasses}

For multiple cuts: Apply $80 \mathrm{lb}$ N/A and all of the recommended $\mathrm{P}_{2} \mathrm{O}_{5}$ and $\mathrm{K}_{2} \mathrm{O}$ in early spring. Apply an additional $80 \mathrm{lb} \mathrm{N}$ and $40 \mathrm{lb} \mathrm{K} 2 \mathrm{O} / \mathrm{A}$ after each cutting, except the last in the fall. Include $20 \mathrm{lb}$ of $\mathrm{P}_{2} \mathrm{O}_{5} / \mathrm{A}$ in the supplemental fertilizer if the soil tested low or medium in $\mathrm{P}$.

For a single, late season cut from pasture: Apply $80 \mathrm{lb}$ N/A if you have not applied $\mathrm{N}$ in the past two months, and apply the soil-test recommended amount of $\mathrm{P}_{2} \mathrm{O}_{5}$ and $\mathrm{K}_{2} \mathrm{O}$. If you have applied $\mathrm{N}$ in the past two months, do not apply any nitrogen now, but do apply the soil-test recommended amount of $\mathrm{P}_{2} \mathrm{O}_{5}$ and $\mathrm{K}_{2} \mathrm{O}$. Any application of fertilizer should be made no later than six weeks before the growing season ends.

\section{Summer Annual Grasses}

Species included are sorghum-sudan hybrids, pearl millet, brown top millet, and Japanese millet.

Apply $30 \mathrm{lb} \mathrm{N} / \mathrm{A}, 50 \%$ of the soil-test-recommended $\mathrm{K}_{2} \mathrm{O}$, and all of the $\mathrm{P}_{2} \mathrm{O}_{5}$ fertilizer in a preplant or at-planting application. Apply $50 \mathrm{lb}$ N/A and the remaining $\mathrm{K}_{2} \mathrm{O}$ after the first grazing period. Apply an additional $50 \mathrm{lb}$ N/A after each subsequent grazing period, except the last.

\section{Warm-Season Legumes or Legume-Grass Mixtures}

Species included are aeschynomene, alyceclover, desmodiums, hairy indigo, stylo, perennial peanut, and other tropical legumes. Apply all of the soil-test-recommended $\mathrm{P}_{2} \mathrm{O}_{5}$ and $\mathrm{K}_{2} \mathrm{O}$ in spring or early summer when seedlings, or regrowth, are 3 to 4 inches tall.

\section{Perennial-Peanut Hay Production}

Apply all of the soil-test-recommended $\mathrm{P}_{2} \mathrm{O}_{5}$ and $\mathrm{K}_{2} \mathrm{O}$ in early spring. Make an annual application of 20 to $30 \mathrm{lb}$ sulfur/A applied as a sulfate (e.g., gypsum, ammonium sulfate, magnesium sulfate, potassium sulfate, potassium magnesium sulfate). After each hay harvest, apply an additional 15 pounds of $\mathrm{P}_{2} \mathrm{O}_{5}$ and 40 pounds of $\mathrm{K}_{2} \mathrm{O}$ per ton of hay removed, unless the soil tests high or very high.

\section{Cool-Season Annual Grasses}

When planting on a prepared seedbed, apply 30 $\mathrm{lb} \mathrm{N} / \mathrm{A}, 50 \%$ of the soil-test-recommended $\mathrm{K}_{2} \mathrm{O}$, and all of the $\mathrm{P}_{2} \mathrm{O}_{5}$ fertilizer in a preplant or at-planting application. Apply $50 \mathrm{lb}$ N/A and the remaining $\mathrm{K}_{2} \mathrm{O}$ after the first grazing period. Apply an additional 50 $\mathrm{lb}$ N/A after each subsequent grazing period. When overseeding established perennial grasses with cool-season annual grasses, apply $50 \mathrm{lb}$ N/A plus all of the $\mathrm{P}_{2} \mathrm{O}_{5}$ and $\mathrm{K}_{2} \mathrm{O}$ after emergence. Apply an additional $50 \mathrm{lb}$ N/A after each subsequent grazing period.

\section{Cool-Season Legumes or Legume-Grass Mixtures}

Species included are all true clovers (white, red, arrowleaf, crimson, subterranean), vetches, lupines, and sweet clover. If legumes such as white clover are already established, or if reseeding annual legumes such as crimson clover are re-establishing from natural seed, apply all of the soil-test-recommended $\mathrm{P}_{2} \mathrm{O}_{5}$ and $\mathrm{K}_{2} \mathrm{O}$ fertilizer in late fall. For new plantings, apply the recommended $\mathrm{P}_{2} \mathrm{O}_{5}$ and $\mathrm{K}_{2} \mathrm{O}$ in a preplant or at-planting application. If legumes are planted in combination with oat, rye, wheat, and/or ryegrass, apply $30 \mathrm{lb}$ N/A in a preplant or at-planting application plus one additional $50 \mathrm{lb}$ N/A application 
after the grass is well established. These recommendations are made assuming adequate soil moisture is available either from rainfall or irrigation. In southern Florida, lack of adequate rainfall during the cool season frequently causes stand failure or limits growth. Under nonirrigated conditions in southern Florida, the probability of inadequate moisture is high and the likelihood that the crop will benefit from applied fertilizer is low, especially on the drier soils.

\section{Alfalfa}

Apply all of the soil-test-recommended $\mathrm{P}_{2} \mathrm{O}_{5}$ and $50 \%$ of the $\mathrm{K}_{2} \mathrm{O}$ fertilizer in late fall. Apply the remaining $\mathrm{K}_{2} \mathrm{O}$ in early spring. If the alfalfa is mechanically harvested rather than grazed, apply an additional $30 \mathrm{lb} \mathrm{P}_{2} \mathrm{O}_{5}$ and $60 \mathrm{lb} \mathrm{K} \mathrm{K}_{2} \mathrm{O} / \mathrm{A}$ after each harvest. An additional application of $100 \mathrm{lb} \mathrm{K}_{2} \mathrm{O} / \mathrm{A}$ in June or July may increase summer survival of alfalfa. Apply $3 \mathrm{lb}$ boron/A per year to alfalfa in three $1 \mathrm{lb} / \mathrm{A}$ applications. Copper and zinc fertilizer may be needed if soil $\mathrm{pH}$ is above 6.5. The lime requirement shown on the soil-test report is adequate for established alfalfa. However, if the alfalfa has not yet been planted, apply and incorporate one ton of lime/A if the soil $\mathrm{pH}$ is below 6.6. Lime is especially important for alfalfa establishment. It is not practical to incorporate lime once the alfalfa is planted.

Fertilizer should contain 15 to $20 \mathrm{lb}$ sulfur/A; apply as a sulfate (e.g., gypsum, ammonium sulfate, magnesium sulfate, potassium sulfate, potassium magnesium sulfate) since elemental sulfur reacts too slowly to supply the sulfur needs of the current crop.

\section{Liming}

The first priority for establishing or replanting a pasture is to adjust soil $\mathrm{pH}$, which is a measure of soil acidity. Dolomitic or calcitic lime can be used and should be applied according to soil-test recommendations. Ideally the lime should be applied and incorporated 3 to 6 months prior to planting.

Surface-applied lime, as in a pasture, neutralizes the soil acidity of the surface soil but has little immediate effect on the soil $\mathrm{pH}$ below the top inch or so. Reliming of established pasture may be necessary following several years of use. Hay fields, where high rates of ammonium-nitrogen fertilizer are used, often need to be limed more frequently. Use soil testing to monitor $\mathrm{pH}$ levels on hay fields.

The target $\mathrm{pH}$ for various forage crops is listed in Table 1. Cool-season or temperate legumes require a relatively high $\mathrm{pH}$. Warm-season perennial grasses, on the other hand, perform well at a lower $\mathrm{pH}$.

\section{Other Important Considerations}

When applying manure, biosolids, and waste materials, producers may apply higher rates than those recommended above, since the cost of nutrients in wastes is usually lower than in purchased fertilizer. However, the producer should not go above rates that are environmentally acceptable. Additionally, timing of nutrient application may be different than those previously recommended because wastes are often difficult to store and must be moved out regularly.

Land owners applying lime-stabiliized sludge should not forget about the liming effect of this material. Check the soil $\mathrm{pH}$ and stop applying the sludge when the soil $\mathrm{pH}$ reaches 6.5. It has been demonstrated this if the $\mathrm{pH}$ goes above 7.0, bahiagrass will die.

See EDIS fact sheet SL 179 Using Waste Products in Forage Production. 
Table 1. Target $\mathrm{pH}$ for different forage crops grown on mineral soils.

\begin{tabular}{||l|l|l||}
\hline \hline Crop Category & Crops Included & Target pH \\
\hline Bahiagrass-south Florida & bahiagrass & 5.0 \\
\hline Bahiagrass-north Florida & bahiagrass & 5.5 \\
\hline Other improved annual grasses & $\begin{array}{l}\text { bermuda, star, limpo, rhodes, suerte, } \\
\text { and digitgrass }\end{array}$ & 5.5 \\
\hline Warm-season annual grasses & $\begin{array}{l}\text { corn, sorghum, sorghum-sudans, } \\
\text { and millets }\end{array}$ & 6.0 \\
\hline Cool-season annual grasses & small grains and ryegrass & 6.0 \\
\hline $\begin{array}{l}\text { Warm-season legumes or } \\
\text { legume-grass mixtures }\end{array}$ & $\begin{array}{l}\text { perennial peanut, stylo, } \\
\text { desmodiums, aeschynomene, } \\
\text { alyceclover, hairy indigo, and other } \\
\text { tropical legumes }\end{array}$ & 6.0 \\
\hline $\begin{array}{l}\text { Cool-season legumes or } \\
\text { legume-grass mixtures }\end{array}$ & $\begin{array}{l}\text { all true clovers (white, red, arrowleaf, } \\
\text { crimson, subterranean), vetches, } \\
\text { lupines, and sweet clover }\end{array}$ & 6.5 \\
\hline Alfalfa & alfalfa & 7.0 \\
\hline \hline
\end{tabular}

